Pengaruh Theosofi dan Freemason ... (Setyahadi Prihatno)

\title{
PENGARUH THEOSOFI DAN FREEMASON DI INDONESIA \\ (Kajian Analitis Simbol-simbol Theosofi dan Freemason dalam Lirik Lagu dan Sampul Kaset Album Grup Musik Dewa 19)
}

\author{
Setyahadi Prihatno \\ Dewan Dakwah Islamiyah Indonesia Jawa Tengah, \\ Pabelan, Kartasura, Sukoharjo Jawa Tengah \\ E-Mail: srtyadi.skh@gmail.com
}

\begin{abstract}
The lyrics and album cover of Dewa 19 wave of criticism with many symbols or emblems that allegedly represent the ancient mystical beliefs and visually turns almost identical to the symbols on the Thesofi anf Freemason. It lead to the possibility of meaning similarity. Four main points discussed in this study is about the meaning of the lyrics of the album's songs of Dewa 19 band, regarding the visual appearance and meaning of symbols in the cover of the album of Dewa 19, reviewing the structure of the relationship between the lyrics and the symbols in the album of Dewa 19 with Theosofi and Freemason, as well as explain the impact of visualization and dissemination of these symbols in a album of Dewa 19 cassette. Dewa 19 has consistently display the lyrics of songs and symbols of Theosofi and Freemasonry teachings started from his first album. Symbols are cleverly laid out in various ways and can only be seen with certain ways. The pattern of symbols has a characteristic appearance as well as its own theme. The structure of relations that are drawn in this study relates to the profile of Ahmad Dhani, Theosofi and Freemason teachings, text and lyrics, as well as a visual display of Theosofi and Freemasons symbols in Dewa 19 album. Display representations of symbols contained in the album cover of Dewa 19 concluded have relevance in form and meaning to the symbols of the teachings or understood Occult, Paganism, Kaballah and Theosofi, as well as movements such as secret Zionist, Illuminati and Freemasonry.
\end{abstract}

Keywords: symbol; theosofi; freemason.

Abstrak: Lirik dan sampul album Dewa 19 menuai banyak kritik dengan banyaknya simbol atau lambang yang diduga merepresentasikan kepercayaan mistik kuno dan secara visual ternyata nyaris identik dengan simbol-simbol pada Theosofi dan Freemason. Hal tersebut mengarahkan pada adanya kemungkinan kesamaan makna. Empat hal utama yang dibahas dalam penelitian ini adalah mengenai makna dari lirik lagu album grup musik Dewa 19, mengenai tampilan visual dan makna simbol dalam sampul album Dewa 19, mengkaji struktur relasi antara lirik lagu dan simbol dalam album Dewa 19 dengan Theosofi dan Freemason, serta menjelaskan dampak dari visualisasi dan penyebaran simbol-simbol tersebut dalam kaset album Dewa 19. Dewa 19 secara konsisten telah menampilkan lirik lagu dan simbol-simbol ajaran Theosofi dan Freemason dari mulai album pertamanya. Simbol secara cerdik diletakkan dengan berbagai cara dan hanya bisa dilihat dengan cara-cara tertentu. Pola pemunculan simbol memiliki ciri serta tema tersendiri. Struktur relasi yang ditarik dalam penelitian ini berkaitan dengan profil Ahmad Dhani, ajaran Theosofi dan Freemason, teks dan lirik lagu, serta tampilan visual simbol-simbol Theosofi dan Freemason dalam album Dewa 19. Representasi tampilan simbol yang terdapat dalam sampul album Dewa 19 disimpulkan memiliki keterkaitan secara bentuk dan makna dengan simbol-simbol dari ajaran atau paham Okultisme, Paganisme, Kaballah serta Theosofi, serta pergerakan-pergerakan rahasia Zionisme Yahudi 
seperti, Illuminati dan Freemasonry.

Kata kunci: symbol; theosofi; freemason.

\section{PENDAHULUAN}

Pengaruh Yahudi di Indonesia berawal dari kedatangan penjelajah dari Eropa yang kemudian menjajah di Nusantara. Pemikiran-pemikirannya dikembangkan dalam perkumpulan Freemasonry.Diantara pemikiran yang berkembang pesat adalah ajaran Theosofi.Menurut A.S. Carpentier Alting sejak sebelum tahun 1756 sudah banyak Mason Bebas (Vrijmetselarij) di Hindia Timur (Indonesia).

Pada awal penjajahan Belanda hanya orang Eropa yang menjadi anggotanya. Fase berikutnya mulailah orang pribumi direkrut untuk menjadi anggota terutama dari kaum ningrat.Siapa saja mereka bisa dilihat dalam buku "Jaringan Yahudi International di Nusantara" karya Artawijaya dan buku "Fakta dan Data Yahudi di Indonesia.Era Repormasi" karya Rizky Ridyasmara.

Secara resmi organisasi Freemason yang telah ada sejak 1762 berakhir 27 Februari 1961 oleh Keputusan Presiden Republik Indonesia Sukarno yang termuat dalam Lembaran Negara Republik Indonesia Nomer 18 tahun 1961 karena azas dan tujuannya dianggap tidak sesuai dengan identitas nasional Indonesia. Termasuk Rotary, Moral Re-armament dan Rosicrucian juga dilarang.

Kenyataanya di kemudian hari para anggota Freemason ini tetap eksis meski sembunyi-sembunyi. Organisasi seperti Rotary Club kembali eksis meski legalitasnya masih perlu dikaji. Kasus besar dan cukup menggemparkan salah satunya adalah kasus Dewa 19 dan Ahmad Dhani yang disinyalir mengusung simbol - simbol Yahudi dan ajaran Theosofi dalam album dan karya-karyanya.

Dipilihnya album grup musik Dewa 19 sebagai obyek juga karena grup musik ini memiliki jutaan penggemar dan sampai dengan hari ini masih eksis di Indonesia dan dunia musik internasional. Tidak menutup kemungkinan melalui album-album berikutnya masih akan menyebarkan simbol dan ajaran Yahudi Freemason di Indonesia.

Kenyataan tersebut mendorong perlu adanya pengetahuan yang cukup untuk mengenali keberadaan dan siapa sejatinya Yahudi, Theosofi dan Freemason.Diharapkan kajian ini akan dapat memberikan pemahaman yang obyektif kepada masyarakat.

Berdasarkan latar belakang di atas ada empat pokok permasalahan yang akan dikaji dari kaset album grup musik Dewa 19 yaitu; pertama,makna dari simbol - simbol yang terdapat dalam album, kedua, lirik lagu yang dipengaruhi ajaran Theosofi dan Freemason, ketiga, struktur relasi antara lirik - lirik lagu dan simbol - simbol dalam album dengan ajaran Theosofi dan Freemason dan keempat, dampak dari pencantuman dan penyebaran kaset album yang mengandung ajaran serta simbol Theosofi dan Freemason.

Tujuan dari penelitian ini adalah untuk membuktikan simbol-simbol dalam kaset album grup musik Dewa 19 identik memiliki kesamaan dengan simbol-simbol Freemason atau Theosofi, mengungkap rahasia pesan yang terkandung didalamnya serta dampak dari visualisasi dan penyebarannya. Secara praktis dan teoritis manfaat penelitian ini dapat menjadi rujukan dalam mengembangkan kajian keilmuan tentang fenomena gerakan Theosofi dan Freemason khususnya di Indonesia.

Kerangka teori sebagai pijakan analisis didasarkan pada tinjauan pustaka dari penelitian sebelumnya serta dokumen pustaka yang mengkaji tentang simbol, biografi Dewa 19, Theosofi dan Freemason.Beberapa penelitian terkait sebelumnya sebagai acuan pustaka digunakan skripsi berjudulMakna Perjalanan Manusia dari Keterpurukan Menuju 
Kehidupan yang Lebih Baik (Analisis Semiotik tentang Lirik Lagu Satu Sisi Milik Kelompok Musik Dewa 19 dalam Album Pandawa Lima) karya Fahmi R. Hidayat, penelitian berjudul "Analisis Gaya Bahasa dalam Lirik Lagu Dewa 19" oleh Egi Pratama dan tesis berjudul Representasi Simbol Zionisme pada Sampul Album Grup Band Dewa karya Twin Agus Pramonojati.

Dokumen pustaka lainnya untuk mengungkap jejak pengaruh Theosofi dan Freemason dalam album tersebut diantaranya adalah, buku berjudul Vrijmetselarij en samenleving in Nederlands Indie en Indonesie 1764 - 1962 karya DR. Th. Stevens dengan penerjemah Pericles Katoppo, M.A. Melengkapi studi pustaka adalah biografi dari Dewa 19 yang ditulis dalam buku berjudul, Manunggaling Dewa Ahmad Dhani karya Ahmad Dhani dan Masyamsul Huda. Ed dan Messages, Signs and Meanings: A Basic Textbook in Semiotics and Communication Theory (Third Edition) karya Marcel Danesi yang diterjemahkan menjadi Pesan, Tanda dan Makna: Buku Teks Dasar Mengenai Semiotika dan Teori Komunikasi.

Mengacu pada penelitian dan dokumen pustaka lainnya dapat diketahui bahwa lirik lagu dan sampul album grup musik Dewa 19 dijadikan sebagai media interaksi komunikasi yang mengekspresikan pesan-pesan tertentu.Pendekatan semiotika digunakan untuk melakukan analisa makna lirik lagu dan simbol tercantum didalam album.Semiotika pada prinsipnya adalah displin ilmu yang mempelajari apapun yang bisa digunakan untuk menyatakan sesuatu kebohongan.Jika sesuatu itu tidak bisa digunakan untuk mengatakan kebohongan, sebaliknya bisa digunakan untuk mengatakan kebenaran. Sejalan dengan itu Eco menegaskan pendapatnya jika tanda dapat digunakan untuk berkomunikasi maka tanda juga dapat digunakan untuk mengkomunikasikan kebohongan. Prinsipnya semiotika adalah disiplin ilmu yang mengkaji segala sesuatu yang dapat digunakan untuk mendustai, mengelabui atau mengecoh . Dengan kata lain tanda dapat dipergunakan untuk menyatakan kebenaran seka- ligus juga kebohongan.

Pendapat beberapa ahli tentang semiotic atau semiologi di atas, dapat diambil suatukesimpulan bahwa semiotic atau semiologi adalah ilmu tentang tafsir tanda, dansistem tanda yang diproduksi oleh manusia.Sobur menyimpulkan secara singkat semiotika dibangun dalam tiga bagian yaitu penyelidikan semiotik (murni, deskriptif dan terapan), hubungan semiotic (syntactics, semantics dan pragmatics) dan kategori sarana informasi (signals, signs dan symbols).

Penelitian ini menggunakan analisis semiologi untuk menafsirkan tanda atau simbol dan juga bagaimana tanda-tanda yang diciptakan tersebutmempunyai maksud atau tujuan tertentu yang lebih pragmatis.Baik untuk dirinya sendiri maupun kepada komunikannya. Little John mengatakan tanda-tanda (sign) adalah basis dari seluruh komunikasi - Dengan kata lain dapat dikatakan bahwa manusia dengan perantaraan tanda-tanda dapat melakukan komunikasi dengan sesamanya.

Analisa terhadap gaya bahasa dalam menulis lirik lagu digunakan untuk memahami pesan-pesan tertentu yang terkandung secara implisit atau tersirat. Gaya bahasa yang dominan dipakai oleh grup musik Dewa 19 adalah gaya bahasa perbandingan. Pembaca atau pendengar bisa mengerti bahwa setiap bait dalam lirik lagunya tidak semata-mata bermakna apa adanya melainkan ada makna yang tersembunyi.

Hal yang sama untuk mengungkap makna dari simbol-simbol pada sampul album. Simbol berdiri dan ada untuk sesuatu yang lain, kebanyakan diantaranya tersembunyi. Simbol dapat berdiri untuk suatu institusi, cara berpikir, ide, harapan dan lainnya. Pengungkapan maknanya digunakan pembanding dari referensi penelitian sebelumnya serta relasi dengan dokumen-dokumen ataupun literatur yang mengungkap data mengenai makna simbolik, sejarah, serta fenomena sosial budaya dari Theosofi dan Freemason.

Berdasarkan pemaparan penelitian dan pustaka yang dijadikan acuan tersebut dia- 
tas maka kajian tentang pengaruh Theosofi dan Freemason melalui simbol-simbol dan lirik lagu dalam album Dewa 19 belum pernah diteliti dan memiliki nilai yang sangat penting bagi bangsa Indonesia umumnya dan kaum muslimin pada khususnya.

\section{METODE PENELITIAN}

Penelitian ini dikategorikan sebagai penelitian kualitatif.Beberapa pendekatan penelitian digunakan untuk menjelaskan hubungan simbol-simbol dalam kaset album grup musik Dewa 19 dengan Theosofi dan Freemason berserta pengaruhnya dalam masyarakat.Pertama, pendekatan perspektif fenomenologis atau interpretative mengarah pada interaksi simbolik.Asumsi interaksi simbolik digunakannya simbol dalam album sebagai media interaksi, berarti siapapun yang berinteraksi dengan Dewa 19 dan bisa menerima simbol itu maka berada dalam kelompok pemikiran yang sama. Kedua, pendekatan historis digunakan untuk menggali asal usul simbol, pikiran dan motif tujuan pencantuman simbol pada album Dewa 19 melalui dalam dokumen-dokumen pendukung yang terpublikasi.Ketiga, menggunakan pendekatan semiotik digunakan untuk mengungkap bahwa lirik lagu dan desain sampul album Dewa 19 mengkomunikasikan sebuah pesan atau makna asli simbol.

Sumber data penelitian diperoleh melalui pengamatan atau observasi terhadap obyek penelitian, wawancara dan dokumentasi.Data primer atau utama yang pertama diambil dari hasil observasi terhadap lirik lagu dan desain sampul album grup musik Dewa 19. Data sekunder atau data pendukung berupa data pustaka atau bahan dokumen yang menguatkan terhadap temuan penelitian.

Tehnik analisa data menggunakan beberapa variasi metode, yaitu analisa deskriptif kualitatif, analisa dokumen dan analisa semiotika. Data yang diperoleh kemudian dianalisis secara berurutan yang terdiri dari tiga tahapan, yaitu: reduksi data dan pengorganisasian data, penyajian data dalam bentuk narasi dan penarikan kesimpulan atau verifkasi . Tahapan berikutnya dilakukan analisa dokumen dan semiotika terhadap data dokumen yang terpilih.

Penarikan kesimpulan terhadap hasil analisa dilakukan dengan metode berpikir induktif (dari pernyataan umum kepada yang bersifat khusus) dan deduktif (dari pernyataan khususkepada yang bersifat umum) - Terakhir data dan kesimpulan yang ada juga akan di analisa dengan prinsip-prinsip atau paradigma ta'sil, taswir, tarsyid, dan tatwir sebagai implementasi worldview Islam.

\section{HASIL DAN PEMBAHASAN}

Aksi panggung Dewa 19 terbukti sering menggunakan asesoris yang menonjolkan simbol illumniati dan paganism, yaitu paham yang sejalan dengan ajaran Theosofi dan Freemason. Simbol Theosofi dan Freeh mason ditampilkan dalam bentuk modifikasi. Simbol-simbol tersebut ditampilkan dengan alasan seni semata dan bukan bersifat SARA atau ideologis tetapi hal ini meragukan dengan visualisasi yang identik dan ucapan terima kasih dari Ahmad Dhani pendiri Dewa 19 atas genetik kakeknya yang berdarah Yahudi serta pengakuannya yang terinspirasi ajaran tasawuf.

Terdapat dan indikasi kuat bahwa Dewa 19 terpengaruh Thesofi dan Freemason. Ada unsur sengajamemasukkan simbol tersebut dalam berbagai design sampul albumnyadengan tujuan tertentu meski motif dan tujuan sesungguhnya di balik visualisasi simbol-simbol tersebut belum bisa diprediksikan.

Hasil intrepretasi makna simbol - simbol dalam sampul kaset album grup musik Dewa 19 dengan pendekatan semiotika dan historis diperoleh temuan bahwaterdapat struktur relasi antara lirik lagu dan simbol dalam sampul kaset album dengan pemahaman Theosofi dan Freemason. Makna lirik lagu dianalisa dengan data dokumen biografi Dewa 19, pandangan Ahmad Dhani dan testimoni dari beberapa pihak menun- 
jukan kedekatan kepada tasawuf yang memiliki kesamaan dengan ajaran Theosofi. Simbol-simbol yang ditampilkan berdasarkan data pembanding diperoleh temuan secara visual terdapat kesamaan yang nyaris identik.Berdasarkan temuan tersebut dapat dipahami adanya kesamaan simbol dan makna yang terkandung didalamnya.

Analisa metode penyebaran simbol simbol Theosofi dan Freemason dalam lirik dan sampul kaset album grup band Dewa 19 menunjukan indikasi dikemas secara kreatif. Lirik dibuat dalam gaya bahasa majas sehingga pesan terhindar dari konflik. Simbol didesain sedemikian rupa sehingga kehadirannya nyaris tidak menimbulkan kecurigaan. Simbol-simbol dan pesan yang dikandung disebarkan melalui berbagai media diantaranya dalam bentuk, video, asesoris fashion, life style, dan identitas kelompok. Simbol yang sering digunakan adalah simbol Mata Satu Lucifer (Evil Eye), Bintang David danEye of Horus.

Dampak visualisasi dan penyebaran simbol adalah pesan - pesan, nilai - nilai atau makna yang tersimpan dalam simbol tersebut dengan cepat akan tersebar luas dan diikuti melalui beberapa proses tahai pan. Tahap pertama para penggemar grup musik Dewa 19 dan publik akan terbiasa memakai asesoris penampilan maupun merchandise lainnya. Tahap kedua, setelah terbiasa orang lebih banyak menyerap dan menerima, tanpa banyak mengkritisi. Tahap ketiga, simbol yang diciptakan akan membawa seseorang ke alam pikiran kelompok atau orang yang membuat simbol tersebut yang dalam hal ini adalah Dewa 19. Sampai akhirnya mereka meniru, mengikuti gaya dan menjadikan penampilan Dewa 19 sebagai gaya hidup.Ironisnya adalah bahwa jutaan penggemarnya di Indonesia notabene generasi muda Islam.

Masyarakat menjadi tertarik pada gerakan Theosofi dan Freemason karena mengajarkan sebuah pandangan hidup jiwa yang timbul dari dorongan batin yang mengungkapkan dirinya dalam upaya berkesinambungan untuk mengembangkan semua sifat roh dan hati nurani sehingga dapat mengangkat manusia dan umat manusia ke tingkat susila dan moral yang lebih tinggi. Ia terapkan dalam pelaksanaan seni hidup yang lebih tinggi . Ajaran para mason ini menjadi bagi cikal bakal pluralisme di Indonesia. Disamping para anggotanya dari beragam etnis, bangsa, dan agama, ajaran Theosofi yang dibawa mengajarkan kesamaan semua agama-agama dan kesamaan Tuhan. Targetnya membangun sebuah nilai-nilai persaudaraan universal yang berlandaskan pada paham humanisme dengan menghapus sekat-sekat agama.Target lainnya adalah menjadikan dunia dalam satu pemerintahan tunggal, Novus Ordo Seclorum .Tujuan untuk merekrut dan membuat persaudaraan masih berjalan hingga sekarang. Pernyataan John B. William dalam Innitiation in The Masonic Life menegaskannya, "Ketika kami meresmikan anggota Ordo Freemason, maka harapannya kami dapat membaginya.Janjinya kami membuat menjadi manusia yang lebih baik.Pertama dia masuk di lodge, menjalani hingga mendapatkan ketenangan yang abadi. Ini adalah cara hidup masonic. Proses untuk mencapai tingkatan yang lebih tinggi meraih persaudaraan di masa datang".

Penelitian ini lebih mengarah pada mengenali dan mengungkap makna simbol-simbol Theosofi dan Freemason sehingga dapat membantu bangsa Indonesia mengambil langkah-langkat tepat mensikapi gerakan tersebut. Termasuk antisipasi kemungkinan bahaya yang mengancam dari gerakan Theosofi dan Freemason dan turuT nannya.

\section{Intrepretasi Makna Simbol-simbol Group Musik Dewa 19.}

\section{Simbol Bintang David (Simbol Zionis Israel)}

Secara umum lambang Yahudi ini terdiri dari lingkaran dan dua segitiga yang menghadap ke atas dan ke bawah.Tetapi lingkarannya dibuang saja, dianggap tidak ada. Jadi, tinggal bentuk dua segitiga yang saling menghadap ke atas dan ke bawah. 


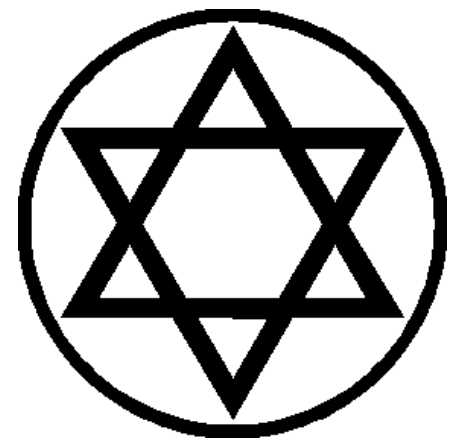

Gambar 4.1 Bintang David

Bandingkan dengan simbol pada liontin kalung yang dipakai oleh Ahmad Dhani pada gambar dibawah ini.Tampak sebuah simbol yang identik. Dari berbagai sumber simbol bintang segi enam (hexagram) ini menunjukkan kepada komunitas Yahudi. Seluruh dunia mengetahui bahwa itu lambang dari negara Israel.Lambang dari Zionisme international yang diyakini memiliki hubungan erat dengan gerakan Freemason dan Theosofi.

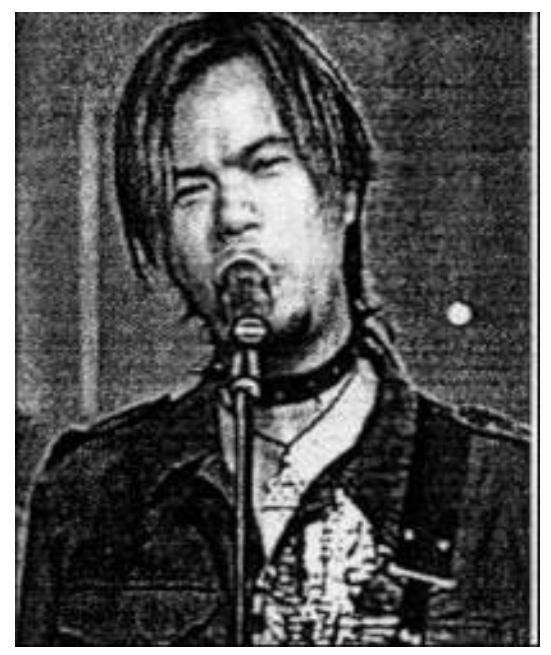

Gambar 4.2 Ahmad Dhani Memakai Kalung Bintang David ${ }^{1}$

Logo seperti itu pun banyak muncul dalam logo-logo perusahaan, organisasi atau lembaga, tetapi bentuknya kerap kali disamarkan. Contohnya di bawah ini:

1 Wongkitos, Fadel, 27 Mei 2013. "Mengungkap Simbol-simbol Yahudi dan Dajjal pada Album Dewa".conspiracyworld.blogspot.co.id. Diakses jam 11.09, tanggal 10 Desember 2015.

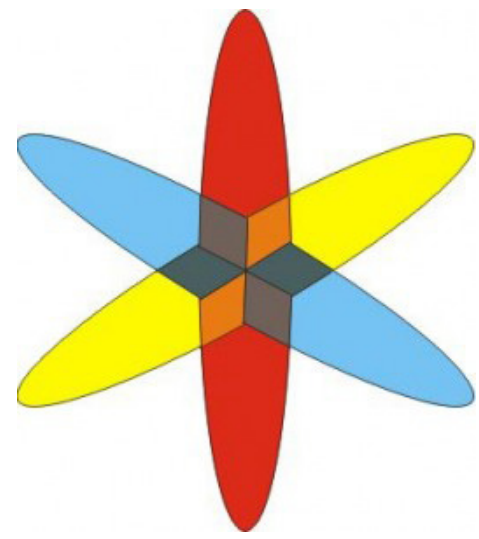

Gambar 4.3 Logo Indosat ${ }^{2}$

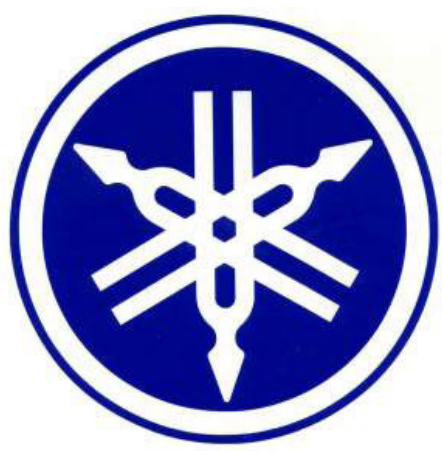

Gambar 4.4 Logo Yamaha ${ }^{3}$

Meski demikian terdapat bantahan bahwa Dhani sering tampil dipanggung dengan memakai kalung Bintang David (simbol Zionis Israel) memiliki tujuan tertentu.Kalung hanyalah sebuah perhiasan tanpa makna apapun. Seperti juga anggota Dewa lain sering memakai kalung simbol agama tidak sesuai agamanya. Bagaimanapun bintang segi enam bukanlah simbol yang dimonopoli Yahudi.Kerajaan yang dulu pernah ada sebelum Turki Ottoman, Karamanoğlu, memakai bintang segi enam sebagai benderanya.Silakan lihat artikel tentang hexagram di wikipedia. Hindu, Buddha, Yahudi, Kristen, dan Islam mengenal bentuk ini dan punya penafsiran masing-masing.

2. Piramida Tak Sempurna (Unfinished Pyramid).

Gambar piramid yang atasnya disamarkan, tapi jika diperbesar akan tampak ada

2 http://abisyakir.files.wordpress.com/2010/02/ bintang-david.gif

3 http://abisyakir.files.wordpress.com/2010/02/logo-yamaha.jpg 
sesuatu di puncaknya. Ini mirip dengan lambang gerakan rahasia Zionisme (Iluminati).

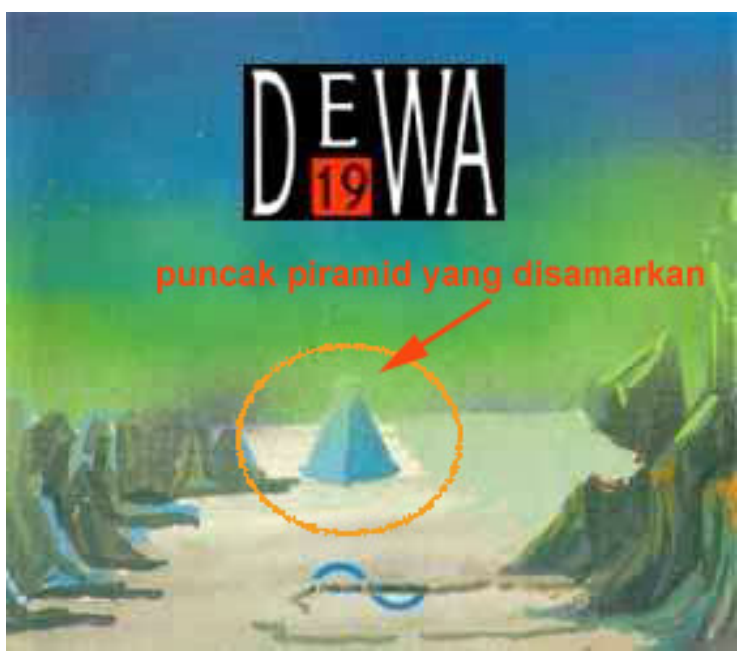

Gambar 4.5 Sampul Album Dewa $19^{4}$

Pada cover album pertama DEWA 19, terdapat gambar Piramida Tak Sempurna (Unfinished Pyramid). Piramida tersebut terpancung dibagian ujungnya.Lambang tersebut sudah dikenal luas sebagai salah satu lambang Yahudi, lambang gerakan Masonis - salah satu organisasi Yahudi, dan juga lambang pada uang 1 dollar Amerika.Dan untuk diingat, dalam mitologi Judaisme angka "19" dikenal sebagai "Dark Star" (Bintang Kegelapan) ${ }^{5}$.

Jika dicermati dengan seksama dan diperbesar gambar puncak piramid yang ditutupi kabut dengan program Windows Picture\&Fax Viewer maka terlihat dipuncak piramid itu walau agak samar, ada sesuatu yang tidak lancip, malah berwarna gelap yang cenderung berbentuk bulat yang bisa jadi merupakan bola, lingkaran, atau juga bisa sebuah mata ${ }^{6}$.

Adanya sebuah obyek diatas simbol piramida di album Dewa 19 mendapat bantahan dari Baladewa (Komunitas penggemar fanatik grup musik Dewa). Menurut

4 Dhani, Ahmad, Manunggaling Dewa Ahmad Dhani, Jakarta: Serambi Ilmu Semesta, 2006, hlm. 92

5 Saidi, Ridwan, Fakta dan Data Yahudi di Indonesia: Dulu dan Kini, Jakarta: Khalifa, 2006, hlm. 134 - 135.

$6 \quad$ Ibid. hlm. 135 mereka sudut selancip apapun dalam raster image yang diolah dengan anti aliasing atau dikompres dengan teknik Lossy seperti JPG akan kehilangan kelancipannya. Hasilnya kalau di zoom sampai 10 kali tidak akan tajam atau kabur dan seolah menimbulkan kesan ada obyek diatasnya ${ }^{7}$.

Dalam dunia simbol dan lambang, gambar piramida dengan sesuatu diatasnya hanya terdapat dalam simbol gerakan masonis.Dikenal dengan simbol piramida terbuka dipuncaknya dan diatasnya terdapat sebuah mata yang disebut The Evil of Eye. Simbol yang sama seperti yang terdapat pada pecahan uang 1 dollar dengan tulisan Annuit Coeptis dan Novus Ordo Seclorum ${ }^{8}$.

Desain uang 1 dollar berupa simbol piramida terbuka dengan mata satu diatasnya sudah tentu dipilih bukan tanpa makna. Perlu diketahui bahwa Unfinished Pyramid dengan Seeing All Eyes adalah salah satu lambang kenegaraan Amerika Serikat (The Great Seal of USA).Semakin mustahil kalau USA memilih lambang negaranya tanpa makna dan nilai historis.Piramida ini disusun dengan 13 lapisan batu.Didasarnya terdapat angka Romawi MDCCLXXVI yang maknanya 1776 tahun kemerdekaan Amerika Serikat. Tetapi para simbolog (ahli simbol) mengatakan pada jumlah besar angka Romawi huruf $\mathrm{M}$ tidak digunakan sehingga tinggal DCCLXXVI yang bila dibaca DC adalah 600, LX adalah 60 dan VI adalah 6, jadi 666. Triple Six angka ini dikenal dengan The Beast Number (angka Iblis). Angka ini sarat dengan filosofi Kabbalah dan dimuat dalam Kitab Wahyu 13:16-18. Tulisan Annuit Coeptis yang berarti "Konspirasi Kita" dan Novus Ordo Seclorumyang berarti The New World Order atau Tata Dunia Baru ${ }^{9}$.

Makna dalam Unfinished Pyramid dengan Seeing All Eyes sangatlah luarbiasa.Bahkan telah bermula sejak ribuan tahun yang

7 http://www.dewa19.com/forums/discuss-fenomena-lambang-yahudi-ahmad-dhani-keturunan-yahudi-t-5813.html

8 Saidi, Ridwan, Fakta dan Data Yahudi di Indonesia. hlm.135

9 Eramuslim digest, The New Jerusalem, edisi koleksi 4, hlm. 53 
lalu. Eramuslim digest dalam tema utamanya yang berjudul The New Jerusalem: A Secret History of Amerika menuliskan Unfinished Pyramid dengan Seeing All Eyes ini adalah lambang Kabbalah (pengikut Iblis) di masa Firaun yang memiliki keterkaitan dengan Kesatria Templar, Perang Salib dan rencana Zionis menguasai dunia serta menyambut kembalinya King of Israel $^{10}$.

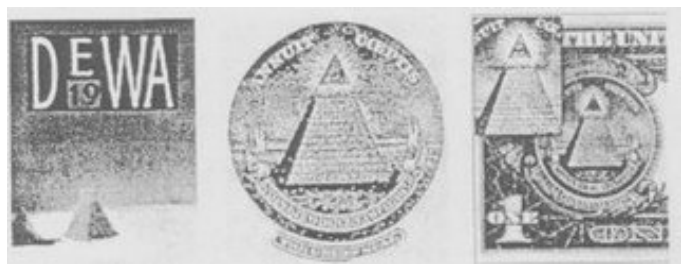

Gambar 4.6 Perbandingan cover dengan 1 Dollar ${ }^{11}$

3. Angka "19" dikenal sebagai "Dark Star" (Bintang Kegelapan).

Angka 19 dalam nama Dewa 19 pada awalnya dipahami sebagai usia personil grup musik tersebut pada saat didirikan rata-rata berusia 19 tahun. Namun menurut
Ridwan Saidi dalam bukunya Fakta dan Data Yahudi di Indonesia halaman 135 dikatakan bahwa dalam mitologi Judaisme angka "19" dikenal sebagai "Dark Star" (Bintang Kegelapan).

Sisi lain kaum Kabbalah yang dalam sejarahnya melahirkan gerakan atau kelompok-kelompok rahasia seperti Knight Templar, Freemasonry danIlluminaty yang mengejawantah menjadi kekuatan Zionisme juga dikenal sebagai Geometrian yang gemar dengan angka dan simbol. Mereka meyakini jika angka dan simbol memiliki ruh dan kekuatan religius ${ }^{12}$.

4. Simbol Dewa Ra (Dewa Matahari Mesir Kuno)

Simbol Dewa Ra ini terdapat pada Cover Album Terbaik-Terbaik. Simbol Dewa RA atau RA Sun of God merupakan Dewa Matahari dalam mitologi Mesir Kuno.Dewa Ra merupakan salah satu dewa kaum Kabbalah di Mesir ${ }^{13}$.

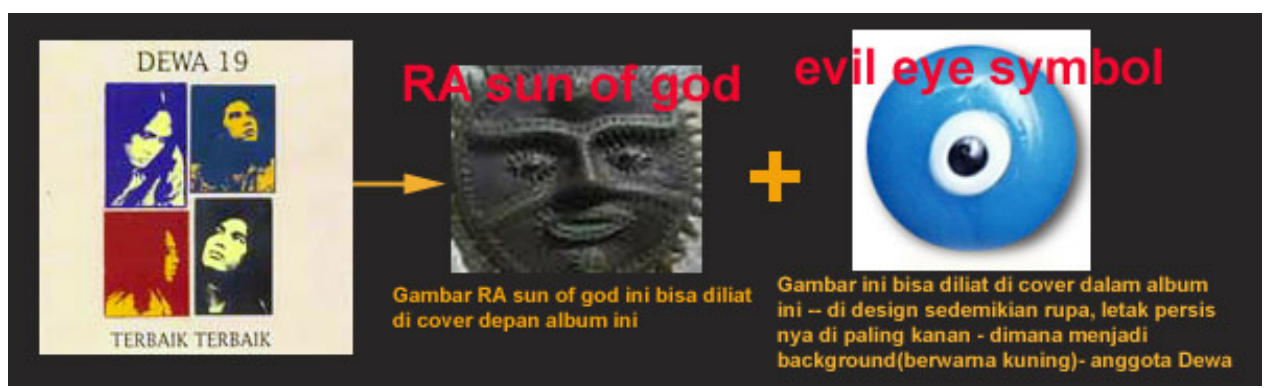

Gambar 4.7 Ra Sun of God ${ }^{14}$

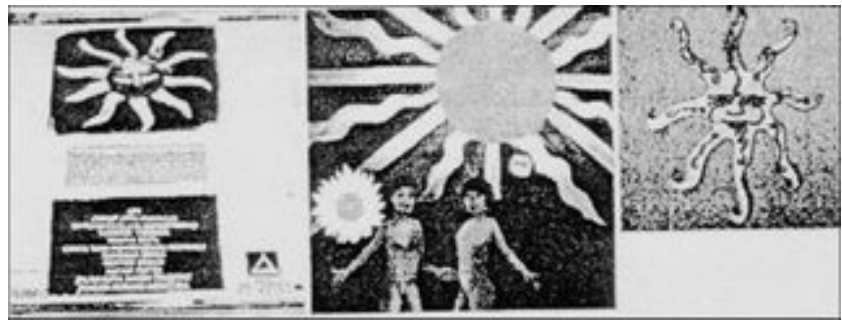

Gambar 4.8 Simbol Dewa $\mathrm{Ra}^{15}$

10 Ibid, hlm. 19

11 Wongkitos, Fadel, 27 Mei 2013. "Mengungkap Simbol-simbol Yahudi dan Dajjal pada Album Dewa".conspiracyworld.blogspot.co.id. Diakses jam 11.09, tanggal 10 Desember 2015.

12 Eramuslim digest, The New Jerusalem, edisi koleksi 4, hlm. 44

13 Saidi, Ridwan, Fakta dan Data Yahudi di Indone- sia. hlm.136

14 http://www.dewa19.com/forums/discuss - fenomena-lambang-yahudi-ahmad-dhani-keturunan-yahudi-t-5813.html

15 Wongkitos, Fadel, 27 Mei 2013. "Mengungkap Simbol-simbol Yahudi dan Dajjal pada Album Dewa".conspiracyworld.blogspot.co.id. Diakses jam 11.09, tanggal 10 Desember 2015. 
5. Protocol Of Zions (Ayat-ayat Iblis) dalam bahasa Ibrani

Simbol ini terdapat dalam Cover Album TERBAIK-TERBAIK.Pada sampulnya terdapat gambar satu halaman Protocol of Zions dalam bahasa Ibrani.Ridwan Saidi (pakar Zionisme) yang menguasai bahasa Ibrani menegaskan, "ini jelas diambil dari satu gambar Protocol of Zions, karena diatas lembaran itu ada judul dan logo.Ini tidak ada dalam Taurat ataupun Talmud"16.

\section{Simbol mata dari Dewa Horus (Eye of Horus)}

Album Cintailah Cinta (2002) pada cover depan album Dewa ini memuat secara mencolok simbol Eye of Horus. Horus adalah Dewa Burung dalam mitologi Mesir Kuno.Sama seperti Dewa Ra, Kabbalah juga mengklaim Horus merupakan salah satu dewa mereka. Di cover dalam juga terdapat simbol yang sekilas mirip mata, tapi sebenarnya merupakan tiruan salah satu simbol yang terdapat dalam buku The Secret Language of Simbol yang disarikan dari kitab Yahudi, Taurat. Simbol ini biasa disebut Femina GeniVegia atau kelamin perempuan yang merupakan salah satu simbol gerakan Freemasonry ${ }^{17}$.

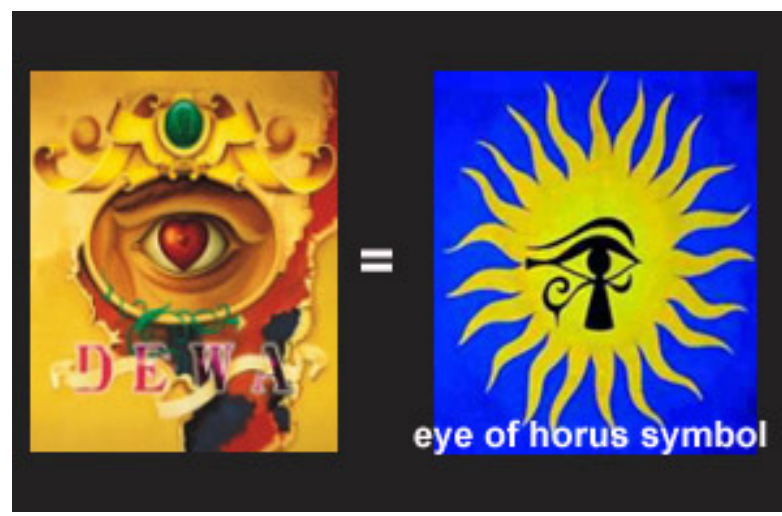

Gambar 4.11 Simbol Dewa Horus (Eye of Horus)

Di sudut kiri bawah ada gambar kepala seorang gadis dengan rambut panjang terurai, dikepala si gadis seolah ada pusa-

16 Saidi, Ridwan, Fakta dan Data Yahudi di Indonesia. hlm.137

17 Saidi, Ridwan, Fakta dan Data Yahudi di Indonesia. hlm.144 ran air. Jika diperbesar maka akan terlihat bahwa "pusaran air" dan rambut si gadis itu sesungguhnya adalah mata dari Dewa Horus $^{18}$.
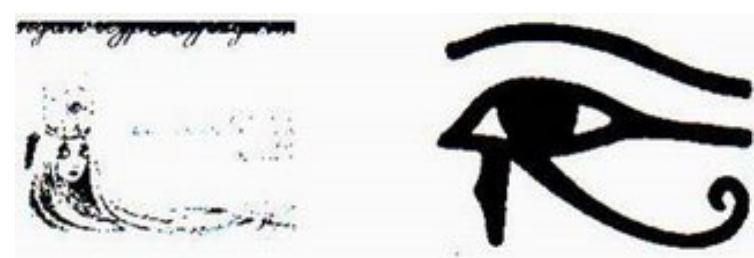

Gambar 4.12 Dewa Horus ${ }^{19}$

Dipermukaan cakram digital (CD) juga berisi simbol okultisme Dewa Horus (juga ada tanda panahnya) yang merupakan salah satu simbol dari gerakan Freemason. Dipiringan disc-nya jika dicermati bergambar kepala burung dengan simbol mata Horus.Yang merupakan salah satu simbol dari gerakan Freemasonry.

\section{Sayap simbol Theosofi}

Dalam cover Album Bintang Lima (2000) terdapat gambar sayap dengan hati di tengah dimuat utuh dengan latar belakang empat personil Dewa. Sedangkan dalam Album CINTAILAH CINTA I \& II (2004), terdapat lambang sayap yang merupakan lambang resmi Dewa dengan latar belakang hitam kelam. Lambang sayap tersebut merupakan simbol perkumpulan Theosofi .Theosofi di Indonesia sengaja dikaburkan dengan aliran Tasawuf meskipun keduanya berbeda.Masuknya Theosofi dalam aliran Tasawuf sudah dimulai ketika Freemason masuk.Mereka berkumpul di Loge yang merupakan tempat ritualnya. Masyarakat lebih mengenalnya sebagai gedung setan. Ritual pengikut Theosofi biasanya memang mengadakan upacara pemanggilan arwah atau jin yang merupakan tradisi dari paganism ${ }^{20}$.

18 Ibid, hlm. 144

19 Wongkitos, Fadel, 27 Mei 2013. "Mengungkap Simbol-simbol Yahudi dan Dajjal pada Album Dewa".conspiracyworld.blogspot.co.id. Diakses jam 11.09, tanggal 10 Desember 2015.

20 Saidi, Ridwan, Fakta dan Data Yahudi di Indonesia. hlm.142 


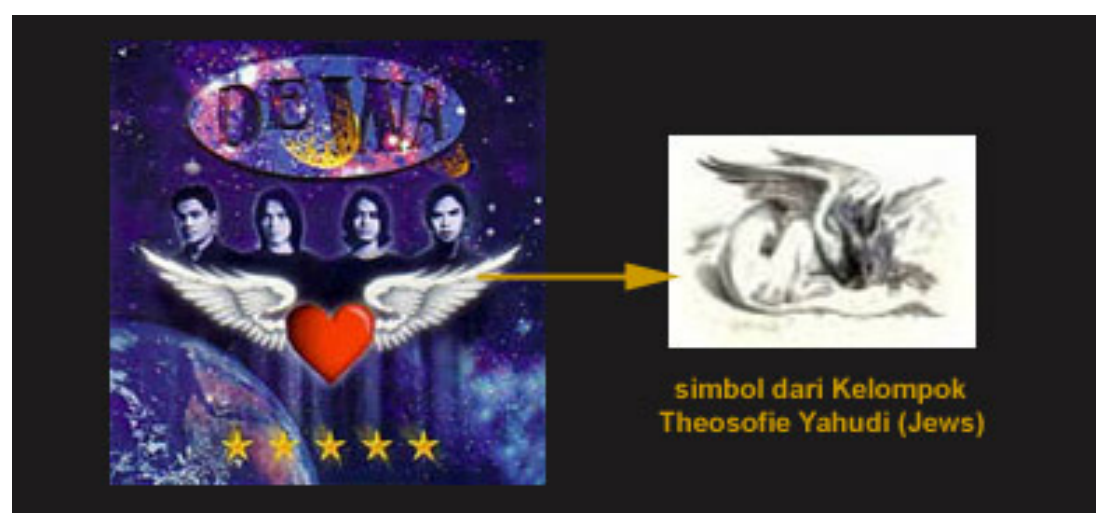

Gambar 4.13 Sayap Simbol Theosofi dalam Album Bintang Lima ${ }^{21}$

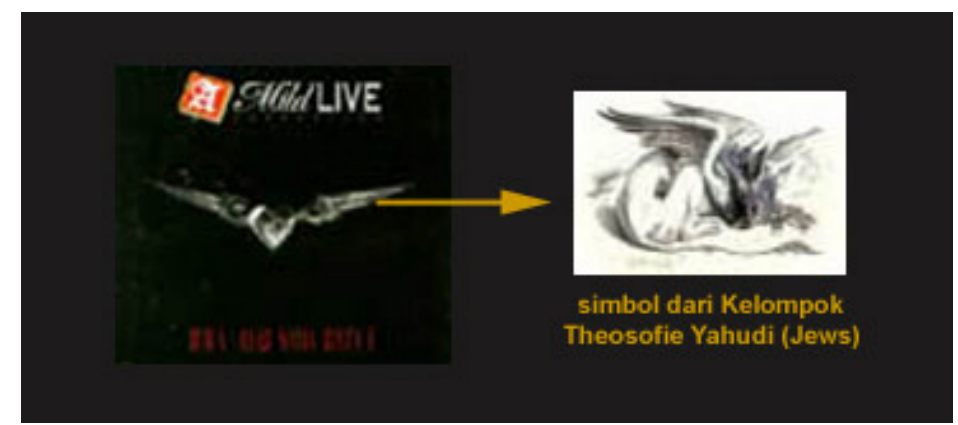

Gambar 4.14 Sayap Simbol Theosofi di Album Atas Nama Cinta I \& II ${ }^{22}$

Indikasi bahwa simbol itu adalah sim- Dhani, sejarah Theosofi dan aliran kebatibol Theosofi dapat dipahami melalui keter- nan di Indonesia yang lebih dikenal dengan kaitan atau relasi antara profil dari Ahmad tasawuf Syaikh Siti Jenar.

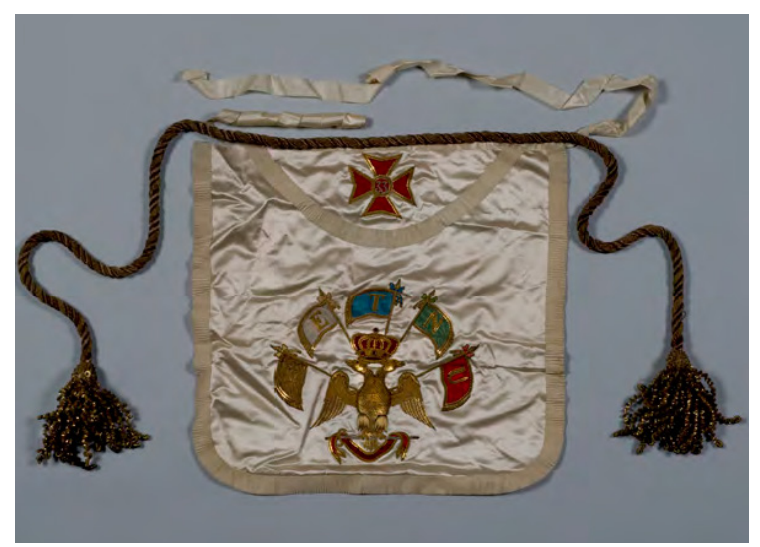

Gambar 4.15 Lambang Freemason ${ }^{23}$

21 Wongkitos, Fadel, 27 Mei 2013. "Mengungkap Simbol-simbol Yahudi dan Dajjal pada Album Dewa". conspiracyworld.blogspot.co.id. Diakses jam 11.09, tanggal 10 Desember 2015.

22 Ibid

23 Aimee E Newell, 2015, “The Badge of The Freemason”. The Northern Light, The magazine for Scottish Rite Masons of America, Lesington, Vol. 46, No. 2, Mei 2015, p. 6. 


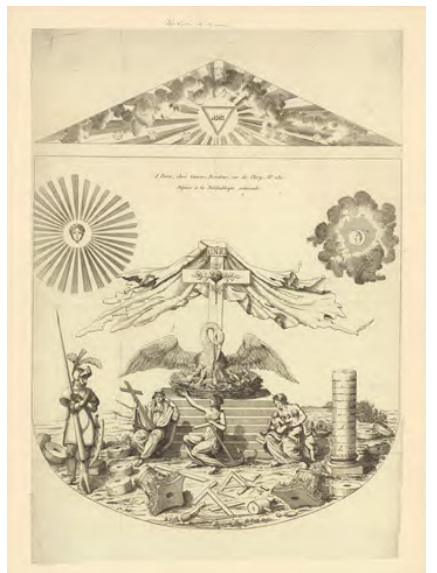
8. Tipologi huruf "Laskar Cinta" adalah huruf Ibrani

Album Laskar Cinta merupakan album ketujuh Dewa dengan menampilkan lambang Allah berbentuk bintang 8 yang dimuat tidak sebagaimana mestinya dan tipologi huruf "Laskar Cinta" dari pola huruf Ibrani / Hebrew font." Pola huruf tulisan Laskar Cinta diambil dari pola huruf Ibrani," ujar Ridwan Saidi ${ }^{25}$.

Gambar 4.16 Lambang Freemson ${ }^{24}$

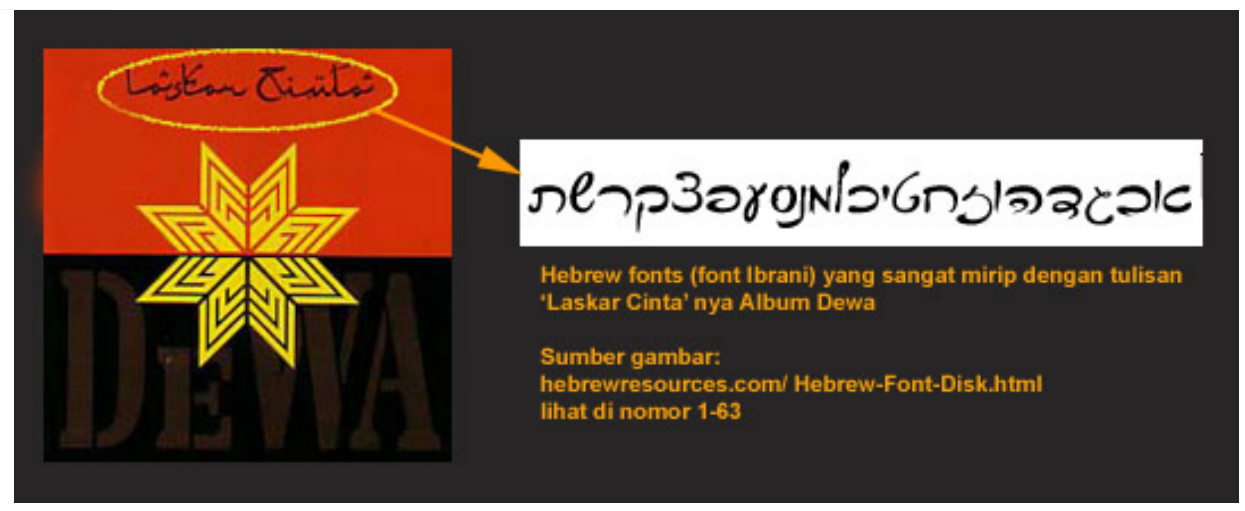

Gambar 4.17 Tipologi huruf “Laskar Cinta” adalah huruf Ibrani ${ }^{26}$

Tipologi huruf "Laskar Cinta" yang (huruf yang digunakan dalam Kitab Yahudibalik, ternyata diambil dari huruf Ibrani

di)

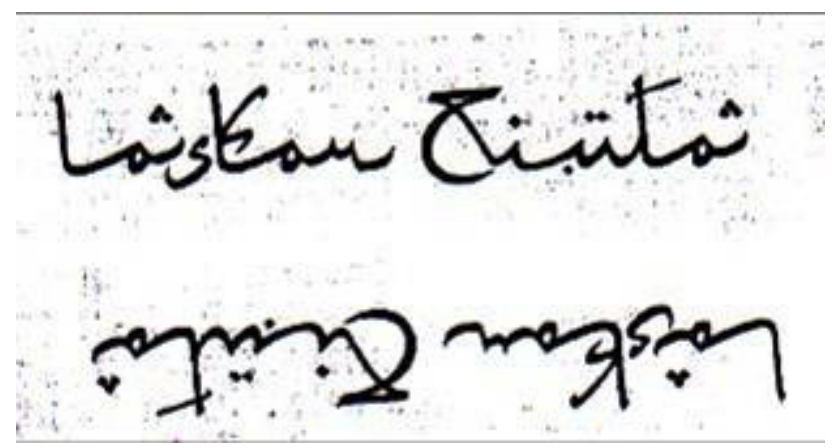

Gambar 4.18 Tipologi huruf "Laskar Cinta" adalah huruf Ibrani ${ }^{27}$

Pada sisi lain dari Album: LASKAR CINTA ini adalah siluet wajah Ahmad Dhani menggunakan peci dengan simbol berpola Arabic bertuliskan "Ahmad" dengan huruf "Alif" bercabang. Jika gambar

24 Ibid, hlm. 8.

25 Saidi, Ridwan, Fakta dan Data Yahudi di Indonesia. hlm.146

26 Ibid, hlm. 146

27 Wongkitos, Fadel, 27 Mei 2013. "Mengungkap tersebut dibalik 180 derajat maka simbol tadi berubah menjadi huruf konsonan mirip bertuliskan YHWH atau YeHWeH atau Yahweh.Sebutan untuk Tuhan tertinggi Yahu$\mathrm{di}^{28}$.

Simbol-simbol Yahudi dan Dajjal pada Album Dewa".conspiracyworld.blogspot.co.id. Diakses jam 11.09, tanggal 10 Desember 2015.

28 Saidi, Ridwan, Fakta dan Data Yahudi di Indonesia. hlm.146 

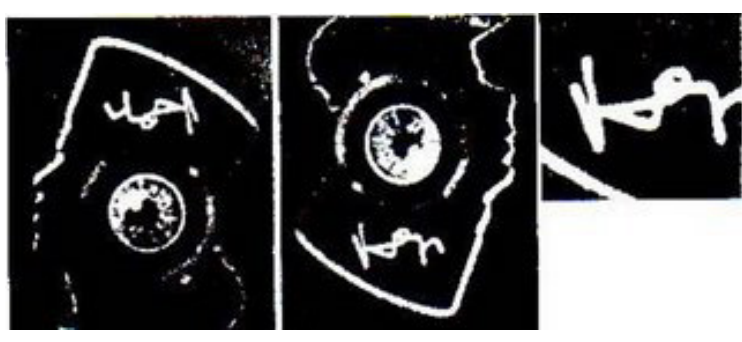

Gambar 4.19 Peci dengan simbol berpola Arabic bertuliskan "Ahmad berubah 180 derajat jadi

"YHWH"29

Benarkah hal demikian? Ada bantahan dari Baladewa tentang hal ini.Wikipedia versi bahasa Ibrani dan melihat bahasannya dalam Bahasa Inggris, lalu bandingkan dengan tulisan terbalik Laskar Cinta memang tidak ada kemiripannya ${ }^{30}$.

\section{Sinar dan Panah Freemason}

Simbol tersebut terdapat dalam cover Album THE BEST OF DEWA 19. Secara kasat mata ada dua lambang yang dimuat: adalah tulisan tangan Italic yang ditumpuk jadi satu sehingga membentuk garis lurus. Satu garis horizontal, satunya lagi vertical, dan saling bersilangan seperti salib miring.

Cover berbentuk horizontal ini baru memiliki arti jika diberdirikan atau diputar 90 derajat kearah kiri (lihat tanda panah biru di sudut atau kanan bawah cover tersebut, itu bukan sekedar gambar panah tapi suatu instruksi) agar 'pesan'nya sampai. Dikepala salib terdapat gambar personil Dewa yang jika dicermati membentuk sebuah bulatan. Ini sama dengan simbol okultisme yang terdapat dalam lambang Dewa Horus ${ }^{31}$.

29 Wongkitos, Fadel, 27 Mei 2013. "Mengungkap Simbol-simbol Yahudi dan Dajjal pada Album Dewa".conspiracyworld.blogspot.co.id. Diakses jam 11.09, tanggal 10 Desember 2015.

30 http://www.dewa19.com/forums/discuss-fenomena-lambang-yahudi-ahmad-dhani-keturunan-yahudi-t-5813.html

31 Saidi, Ridwan, Fakta dan Data Yahudi di Indonesia. hlm.140

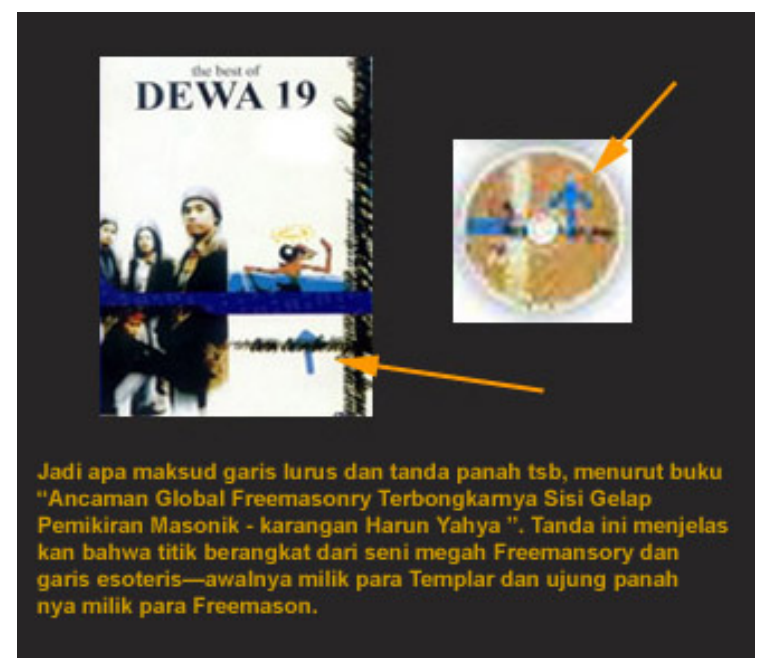

Gambar 4.20 Simbol Sinar dan Panah Freema$\operatorname{son}^{32}$

Harun Yahya dalam bukunya Ancaman Global Freemansory menyatakan bahwa tanda ini menjelaskan bahwa titik berangkat dari seni megah Freemansory dan garis esoteric pada awalnya adalah milik para Templar dan ujung panahnya milik Freemason.

Pada pinggiran discnya terdapat simbol panah dan garis lurus yang saling memotong seperti salib.Lambang garis tersebut sebenarnya sinar yang saling memotong.Ini salah satu simbol dari gerakan Freemansonry. Lambang sinar yang saling memotong ini secara "kreatif" juga terdapat dalam cover kaset bagian dalam dan depan secara keseluruhan.

Berdasarkan interpretasi makna dari simbol-simbol yang digunakan pada desain cover atau sampul album grup musik DEWA diketahui terdapat kemiripan, modifikasi atau bahkan identik dengan simbol-simbol Yahudi, ajaran Theosofi dan gerakan Freemasonri.

\section{Intrepretasi Makna Lirik Lagu Album Grup Musik Dewa 19.}

Analisa terhadap makna lirik lagu album grup musik Dewa yang dianggap memiliki keterkaitan dengan pemahaman Theosofi dan Freemason dilakukan melalui

32 Wongkitos, Fadel, 27 Mei 2013. "Mengungkap Simbol-simbol Yahudi dan Dajjal pada Album Dewa".conspiracyworld.blogspot.co.id. Diakses jam 11.09, tanggal 10 Desember 2015. 
pendekatan semiotika. Dalam semiotika terdapat suatu proses tanda yang meliputi lima komponen yang saling berhubungan atau semiotic relation (hubungan semiotik). Yaitu sign (tanda), interpreter (penafsir), effect (pengaruh), reference (rujukan) dan context (konteks)/conditions (kondisi). Melalui pendekatan ini secara sistematik dapat dijelaskan jalinan tanda yang meliputi esensi, ciri-ciri dan bentuk suatu tanda serta proses signifikasi yang menyertainya.

Berdasarkan pendekatan teori tersebut maka lirik-lirik lagu dalam album grup musik Dewa merupakan sign (tanda) yang akan dianalisa maknanya. Sedangkan penulis menjadi interpreter dari lirik lagu Ahmad Dhani ataupun grup musik Dewa 19. Dalam proses intepretasi makna lirik-lirik lagu tersebut perlu dipahami pula, reference, effect, kondisi latar belakang pemikiran Ahmad Dhani ataupun grup musik Dewa 19. Ahmad Dhani sebagai tokoh sentral dari grup musik Dewa 19 diketahui banyak terinspirasi dan dipengaruhi tokoh-tokoh sufi dalam membuat lirik lagunya.

Hal ini terungkap melalui pernyataan atau pengakuan Ahmad Dhani yang mengucapakan terima kasih kepada Syaikh Lemah Abang dan Al Halajj. Dalam video clip album lagu "Satu" para personel Dewa menggunakan kostum khas yaitu pakaian tarian Darwis yang merupakan tarian khas Sufi. Tarian Darwis sendiri dipopulerkan oleh Jalaluddin Rumi. Data-data pendukung lainya adalah nama tiga orang anaknya yang menggunakan nama tokoh sufi Al Ghzali, Abdul Qodir Jaelani dan Jalaluddin Rumi. Lebih jelas lagi dalam buku yang berjudul buku berjudul Makrifat Cinta Ahmad Dhani dibahas tentang para tokoh Sufi yang mempengaruhi lirik lagu-lagunya.

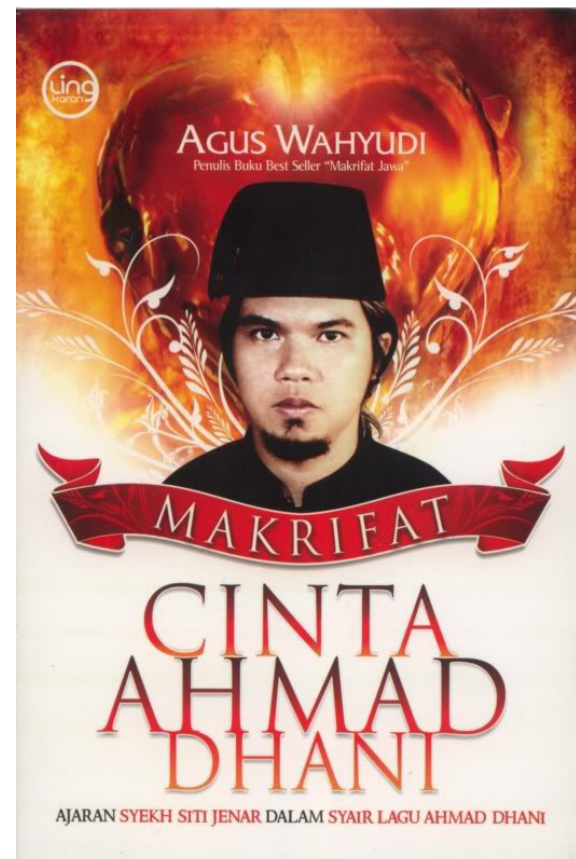

Gambar 4.23 Sampul Buku Makrifat Cinta Ahmad Dhani ${ }^{33}$

Maka tokoh-tokoh Sufi tersebut berfungsi sebagai effect dan reference guna memaknai lirik lagu Dewa 19 yang merupakan sign (tanda). Dengan mengetahui rujukan Ahmad Dhani dalam membuat lirik lagunya maka diharapakan interpretasi yang dilakukan akan mendekati makna yang dimaksud atau tersembunyi.

Rabiah al Adawiyah seorang sufi wanita yang hidup abad ke 2 hijrah dari Bashrah Irak. Rabiah dikenal dengan syair-syair cinta (mahabbah) kepada Tuhan.Karya lirik lagu Ahmad Dhani yang terinspirasi dari Rabiah adalah lagu Jika Surga dan Neraka Tak Pernah Ada yang dinyanyikan oleh Chrisye. Husain Manshur al Hallaj seorang tokoh tasawuf yang hidup pada tahun 244 $\mathrm{H}$ dari desa Thour, Iran.Al Hallaj dihukum mati oleh penguasa dikarenakan salah satu ucapannya yang terkenal "ana al haqq" (aku adalah al haqq atau Tuhan).Dari Al Hallaj inilah berkembang ajaran-ajaran tasawuf. Kepadanya Ahmad Dhani sampai memberikan ucapan terima kasih khusus dalam albumnya.

Abu Hamid Al Ghazali seorang tokoh

33 Sampul Buku Makrifat Cinta Ahmad Dhani, https://www.google.co.id/imgres?imgurl 
yang sangat termasyur dalam peradaban Islam.Lahir pada tahun $450 \mathrm{H}$ dikota Thus, Iran.Karya besarnya adalah kitab Ihya' Ulum ad Din.Dia banyak membahas tasawuf dan syariat sehingga dianggap sebagai jembatan antara tasawuf dan syariat. Bukti kekaguman Dhani adalah anaknya diberi nama $\mathrm{Al}$ Ghazali. Abdul Qodir Al Jaelani atau yang dikenal dengan Sultan al Auliya' (Sultannya para Wali). Hidup antara $470 \mathrm{H}-561 \mathrm{H}$ di kota al Jeal, Iran. Ketika meninggal dimakamkan di Baghdad.Para pengikutnya dikenal dengan Thariqot Qodiriyah. Anak Dhani lainnya diberi nama dengan tokoh ini dan dikenal dengan panggilan "Dul".

Ibnu Arabia atau lengkapnya Muhammad ibn Ali Ibn Muhammad Muhyiddin ibn Arabi ath Tha'I al Hatimin.Bergelar Asy Syaikh al Akbar (guru besar) dan Muhyi ad Din (penghidup agama). Beliau putra dari Ibn Rusyd yang lahir di Murcia, Andalusia Tenggara, Spanyol, tahun $560 \mathrm{H}$, dari keluarga berpangkat, hartawan, dan ilmuwan. Meninggal pada tahun 638 H. (1240 $\mathrm{M})$.Namanya biasa disebut tanpa "Al" untuk membedakan dengan Abu Bakar Ibn Al 'Arabi, seorang qadhi dari Sevilla yang wafat tahun $543 \mathrm{H}^{34}$.

Jalaluddin Rumi seorang tokoh sufi yang hidup tahun 1207 - 1273 M di Persia. Pada salah satu video clip lagu "SATU" para personel Dewa 19 memakai kostum Darwis pakaian khas tarian sufi. Dan Jalaluddin Rumi adalah yang mempopulerkan tarian tersebut.Dikenal sebagai penguntai syair yang handal sehingga Dhani banyak mengambil syair-syair Rumi untuk lagu-lagunya. Sedemikian mengidolakan anaknya diberi nama El Jalaluddin Rumi.

Syaikh Siti Jenar atau Syaikh Lemah Abang yang hidup semasa dengan walisongo di Tanah Jawa, Nusantara.Dikenal dengan ajaran Manunggal ing kawulo Gusti. Dhani khusus mengucapkan terima kasih untuk tokoh ini dalam albumnya.Banyak lirik lagunya yang diyakini memiliki keterkaitan dengan pemahaman Syaikh Siti Je-

34 http://perdhanakid.blogspot.com/2010/02/ bab-i-pendahuluan-1.html nar.

Lirik lagu Ahmad Dhani setelah dikaji memiliki tema pokok yang yaitu berbicara tentang cinta.Cinta birahi kepada lawan jenis, cinta kepada sesame manusia, cinta kepada makhluk lainnya dan bertutur tentang cinta kepada Sang Khalik.Dalam khazanah tasawuf unsur cinta (mahabbah) menjadi dasar dalam ibadah.Ibadah yang berdasarkan cinta memiliki nilai lebih dihadapan Tuhan.Manusia diperintahkan dalam aktivitas kehidupannya untuk melandaskan pada rasa cinta dan kasih sayang.Manusia juga diperintahkan mengenal (ma'rifat) Tuhan.Makrifat juga menjadi landasan utama untuk beribadah.Unsure ma'rifat dan mahabbah menjadi pilar bagi para Sufi untuk menghamba kepada Allah.Ahmad Dhani sebagai musisi yang menerapkan ajaran tasawuf menyadari hal ini.Syair atau lirik lagunya pun terasa sarat dengan muatan ma'rifat dan mahabbah ${ }^{35}$.

1. Lirik lagu "Mistikus Cinta" pada Album Atas Nama Cinta ${ }^{36}$

\section{Mistikus Cinta}

Ketika pertama kali, jiwamu ingin selalu dekat dengan jiwaku yang belum, bisa menterjemahkan segala arti pertemuan ini, arti cumbu rayu ini yang mungkin bisa memusnahkan, kenyataan yang terjadi

Reff :

ketika jiwamu, merasuk ke dalam, aliran darahku dan meracuniku ketika jiwamu, memalukan itu, dan biarkan jiwaku cumbui jiwamu Ketika kamu angkuh, melebur menjadi satu dan hanya waktu yang mungkin bisa memahami apa yang terjadi apa yang sedang kurasa, apa yang sedang kau rasa adalah cinta yang tak bisa yg di jelaskan dengan kata-kata 
Dilihat dari judul lagunya sudah melukiskan siapa Ahmad Dhani dan makna dari lagu tersebut.Mistikus merupakan sebutan lain bagi seorang Sufi. Dalam lagu tersebut Tuhan digambarkan dalam makna kiasan atau majaz sebagai Diri yang berjiwa.Bukan dalam pengertian Tuhan memiliki jiwa sebagaimana manusia. Hakikatnya semua jiwa adalah satu seperti dalam Al Quran surat An Nisa ayat 1 yang artinya "Hai manusia bertaqwalah kepada Tuhanmu yang telah menciptakan kamu dari jiwa yang satu". Jiwa satu tersebut bisa ditafsirkan sebagai jiwa Adam As ataupun nur Muhammad sebagai tajalli (penampakan) Tuhan yang pertama. Maka syair lagu tersebut dimaknai sebagai peleburan antara manusia dan nur Muhammad hingga terasa musnah. Dan ini merupakan jalan menuju manusia sempurna (insan $k a-$ mil). Syair ini menggambarkan penyatuan diri terhadap hakikat dirinya sendiri. Dalam khazanah tasawuf ada tiga langkah menuju wihdah (penyatuan). Pertama takhalli atau pengosongan diri.Memfanakan diri bahwa diri ini hakikatnya tidak ada.Apa yang tampak dalam diri manusia hanyalah penampakan Tuhan yang paling luar. ${ }^{37}$

2. Lirik lagu "Satu" pada Album Laskar Cinta $^{38}$

\section{SATU}

Aku ini...adalah dirimu

Cinta ini...adalah cintamu

Aku ini...adalah dirimu

Jiwa ini... adalah jiwamu

Rindu ini adalah rindumu

Darah ini adalah darahmu

Reff :

Tak... ada yang lain..selain dirimu

Yang selalu ku puja...ouo...

Ku...sebut namamu

Disetiap hembusan nafasku

Kusebut namamu...

Kusebut namamu...

Dengan tanganmu...aku menyentuh

Dengan kakimu....aku berjalan

Dengan matamu...ku memandang

37 Ibid, hlm. $64-67$

38 Ibid, hlm. 70
Dengan telingamu...ku mendengar

Dengan lidahmu...aku bicara

Dengan hatimu....aku merasa

Reff...Reff...Reff...Reff

"THANKS TO: SYEKH LEMAH

ABANG"

Tentang lirik lagu 'SATU' apakah itu mengajarkan aliran Manuggaling Kawula Gusti maka hal tersebut dibantah. Mengutip dari www.dewa19.com pada forum diskusinya menyatakan bahwa Manuggaling Kawula Gusti (bersatunya mahluk dengan Tuhannya) itu adalah ajaran sufistik tingkat tinggi, kalau dilihat sekilas, maka terkesan bahwa mahluk mengaku sebagai Tuhan, harus cermati, bukankah kita pancaran cahaya Tuhan (Allahu nurus samawati wal ardh) kalau melihat dari syair atau lirik lagu SATU, dengan matamu aku memandang, dengan telingamu aku mendengar, dengan lidahmu aku bicara bukankah melakukan segala sesuatu berdasarkan perintah Tuhan. Dengan lidahmu aku bicara bukankah kalau kita berbicara harus berdasar 'lidah' Tuhan, melihat berdasarkan 'mata' Tuhan, sehingga kalau dilihat syair SATU secara jeli maka pencerahan yang akan didapatkan. Mengenai Syah Siti Jenar, bahwa Walisongo tidak pernah menyuruh untuk memenggal Syah Siti Jenar. Itu adalah trik politik adu domba sehingga berkesan ada perselisihan yang membuat umat terpecah.Walisongo meminta pada Syah Siti Jenar untuk tidak mengajarkan dulu ajarannya karena umat masih awam. SALAM BALADEWA ${ }^{39}$.

3. Lirik lagu "Pangeran Cinta" pada Album Laskar Cinta ${ }^{40}$

\section{"Pangeran Cinta"}

Detik-detik berganti dengan detik Menit pun silih berganti Hari-hari pun terus berganti

Bulan-bulan juga terus berganti Jaman-jaman pun terus berubah

39 http://www.dewa19.com/forums/discuss-fenomena-lambang-yahudi-ahmad-dhani- keturunan yahudi-t-5813.html

40 Ibid, hlm. 67 
Hidup ini juga pasti mati

Semua ini pasti akan musnah

Tetapi tidak cintaku padamu

Karena aku sang pangeran cinta

Malam malam diganti dengan pagi

Pagi pun jadi siang

Tahun-tahun pun berganti abad

Yang muda pun pasti menjadi tua

Musim-musim pun terus berganti

Hidup ini juga pasti mati

Tak akan ada yang abadi

Tak akan ada yang kekal

Lirik ini bukan bermakna cinta kepada manusia. Ahmad Dhani sendiri menyatakan lirik tersebut mencerminkan Al Quran surat Ar Rahman ayat 27 yang artinya "Semua yang ada di bumi akan binasa. Dan tetap kekal wajah Tuhanmu yang mempunyai kebesaran dan kemuliaan".Ayat ini sering dirujuk kaum Sufi yang menyukai pernyataan la wujuda illallah (tiada wujud kecuali Allah). Para ahli senjarah tasawuf mengkategorikan sebagai kelompok wujudiyah ${ }^{41}$. Demikian pula dalam surat Al Qoshosh ayat 88 yang artinya " ...tiap-tiap sesuatu pasti binasa kecuali wajahNya...". Dapat dipahami lirik ini jelas memiliki kaitan erat dengan keabadian Tuhan.

Syaikh Siti Jenar dalam pandangannya meyakini bahwa hidup di dunia ini sebenarnya adalah mati.Sedangkan kehidupan yang sesungguhnya adalah ketika mati. Pemikiran lagu diatas menyatakan bahwa ala mini akan binasa, musnah dan tidak ada atau mati. Hidup yang sesunguhnya adalah ketika sudah menyatu dengan Yang Kekal yaitu Tuhan ${ }^{42}$. Ahmad Dhani menyebut dirnya Pangeran Cinta yang cintanya akan terus abadi sementara lainnya akan musnah. Pernyataan ini sangat bersesuaian dengan konsep kesatuan wujud (wihdatul wujud).

4. Lirik lagu "Hidup ini Indah" pada Album Laskar Cinta ${ }^{43}$

41 Dhani, Ahmad, Manunggaling Dewa Ahmad Dhani, Jakarta: Serambi Ilmu Semesta, 2006. hlm. 79

42 Ibid, hlm. 69

43 Ibid, hlm. 72

\section{Hidup Ini Indah}

Matahari menyinari seisi bumi

Seperti Engkau menyinari ruh dalam

jasadku ini

Selamanya seperti hujan

Kau basahi jiwa yang kering

Hidup ini indah bila aku selalu

Ada di sisiMu setiap waktu

Hingga aku hembuskan nafas yang

terakhir

Dan kita pun bertemu

Kau bagai udara yang ku hirup

Di setiap masa Engkaulah darah

Yang mengalir dalam nadiku

Maafkanlah selalu salahku

Karena Kau memang pemaaf

Dan aku hanya manusia

Hanya Kau dan aku

Dalam awal dan akhir

Lirik lagu ini menyiratkan hasrat kerinduan kepada Tuhan yang menyinari ruh dalam jasad.Meski dunia bersifat fana tetapi menjadi bermakna apabila dekat dengan Tuhan. Hingga muncul perasaan dalam hati tak ada yang lain dalam dunia ini kecuali yang ada hanyalah Kau dan aku dalam awal dan akhir. Terlihat pula disini adanya kecenderungan pemahaman kesatuan hamba dan Tuhan.

5. Lirik lagu "Nonsense" pada Album Laskar Cinta ${ }^{44}$

\section{Nonsens}

Bila ada adalah..tidak ada

Bila apa yang... kau tahu salah

Bila apa yang... kau dengar bohong

Apakah langit..

Memang ada diatas kita

Apakah langit..

Memang biru biru warnanya

Apakah langit..

Memang benar-benar adanya

Tak ada kebenaran hakiki

Yang ada cuma hanya

Kamu disana

Dan akulah milikmu

44 Ibid, hlm. 74 
Keyakinan akan sebuah kebenaran

Bukanlah kebenaran

Kebenaran yang sejati

Bila tak benar... diuji kebenarannya

Lirik lagu berjudul "Nonsense" ini menyatakan bahwa kebenaran di dunia ini bersifat relative atau subyektif.Kebenaran dalam hidup ini adalah fatamorgana, semu dan tidak nyata.Kebenaran hakiki tidak pernah dijumpai manusia dalam kehidupan di dunia. Ahmad Dhani dalam melalui lirik lagu ini mengisyaratkan bahwa kebenaran sejati hanyalah milik Tuhan.Kalau ada yang mengatakan keyakinannya adalah yang paling benar maka sebenarnya hal itu bukanlah kebenaran sejati.

6. Lirik lagu "Hadapi dengan Senyuman" Album Laskar Cinta ${ }^{45}$

\section{Hadapi Dengan Senyum}

Hadapi dengan senyuman

Semua yang terjadi biar terjadi

Hadapi dengan tenang jiwa

Semua kan baik-baik saja

Bila ketetapan Tuhan

Sudah ditetapkan, tetaplah sudah

Tak ada yang bisa merubah

Dan takkan bisa berubah

Relakanlah saja ini

Bahwa semua yang terbaik

Terbaik untuk kita semua

Menyerahlah untuk menang

Lirik lagu ini mengisyaratkan sikap kepasrahan (tawakal) dan menerima (qonaah). Apapun yang yang ditetapkan oleh Tuhan adalah menjadi takdir yang tidak dapat dirubah oleh siapapun. Menerima ketetapan dan meyakini apa yang diberikan Tuhan adalah yang terbaik. Menerima dengan keikhlasan.

7. Lirik lagu "Laskar Cinta1 \& 2" pada Album Republik Cinta ${ }^{46}$

\section{Laskar Cinta (Chapter 1)}

45 Ibid, hlm. 78

46 Ibid, hlm. 80
Wahai, jiwa jiwa yg tenang berhati-hatilah dirimu kepada

Hati hati yang penuh dengan keben-

cian yang dalam

Karena, sesungguhnya iblis ada dan bersemayam

Di hati yang penuh dengan benci dihati Yang penuh dengan prasangka

Laskar cinta sebarkanlah benih-benih cinta

Musnahkanlah virus-virus benci Virus yang bisa merusakkan jiwa

Dan busukkan hati

Laskar cinta ajarkanlah ilmu tentang cinta

Karena cinta adalah hakikat

Dan jalan yang terang bagi semua manusia

Jika kebencian meracunimu

Kepada manusia lainnya maka sesungguhnya iblis sudah berkuasa atas dirimu Maka jangan pernah berharap aku akan mengasihi menyayangi Manusia manusia yang penuh benci seperti kamu Laskar Cinta (Chapter 2)

Wahai jiwa-jiwa yang tenang jangan sekalikali kamu

Mencoba jadi Tuhan dengan mengadili dan menghakimi

Bahwasanya kamu memang tak punya daya dan upaya.

Serta kekuatan untuk menentukan

kebenaran yg sejati

Bukankah kita memang tercipta laki

laki \& wanita

Dan menjadi suku suku bangsa yang pasti berbeda

Bukankah kita harus saling mengenal dan menghormati

Bukan untuk saling bercerai berai dan berperang angkat senjata

Dhani dalam lirik lagu ini membicarakan tentang pesan kepada jiwa-jiwa yang tenang (nafsu al muthma'innah).Juga tentang adanya Iblis yang senantiasa menggoda dengan membawa kebencian. Upayanya meraih ketenangan jiwa akan diiringi den- 
gan bujuk rayu Iblis. Diantara bujuk rayu Iblis adalah dengan menumbuhkan sikap fanatisme yang dilampiaskan dengan sikap membenci dan bahkan merusak.

Analisa terhadap beberapa lirik lagu grup musik DEWA tersebut diatas dalam pendekatan semiotika merupakan sign (tanda). Album tersebut penuh dengan sign (tanda). Menggunakan nama-nama tokoh sufi pada desain cover, symbol-simbol, ungkapan-ungkapan dan latar belakang pandangan religius Ahmad Dhani. Termasuk pandangan beberapa pihak serta data pendukung lainnya yang termuat dalam buku Makrifat Cinta Ahmad Dhani dan buku Manunggaling Dewa Ahmad Dhani semakin menegaskan adanya makna simbolik dibaliknya yang berhubungan dengan pemahaman tasawuf dan ajaran manunggaling kawula gusti atau wihdatul wujud Syaikh Siti Jenar dan Al Hallaj.

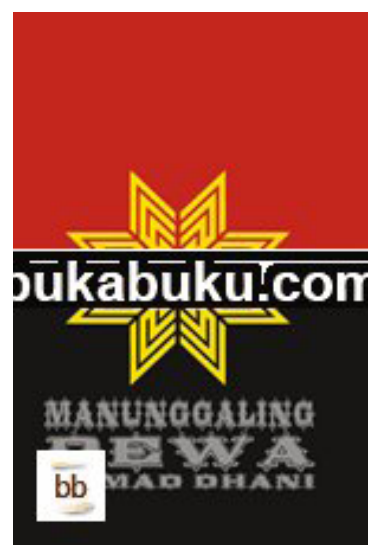

Gambar 4.24 Buku Manunggaling Dewa Ahmad Dhani ${ }^{47}$

Album Dewi Persik yang dikelola Republik Cinta Manajemen pimpinan Ahmad Dhani Manaf juga menampilkan SimbolHyreoglyph Eye Of Horus.

47 https://www.google.co.id/imgres?imgurl

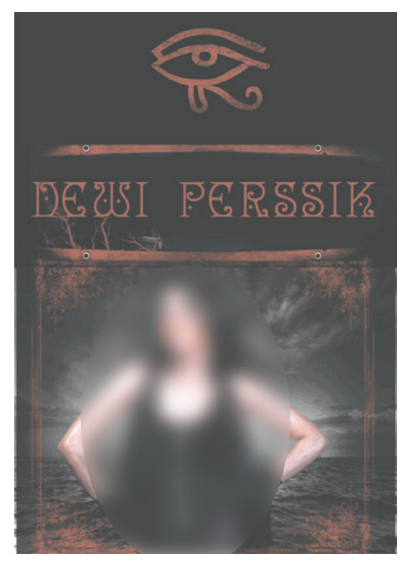

Gambar 4.25 Sampul Album Dewi Persik ${ }^{48}$

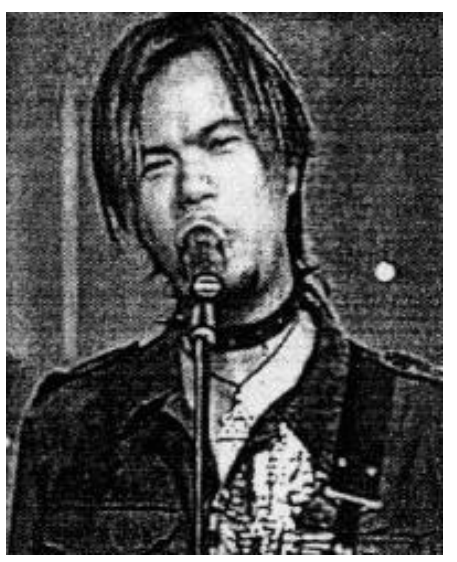

Gambar 4.26 Ahmad Dhani dengan Asesoris Kalung Bintang David ${ }^{49}$

\section{KESIMPULAN}

Kajian analitis terhadap simbol - simbol Theosofi dan Freemason dalam lirik dan sampul kaset album grup musik Dewa 19 dapat dikemukakan beberapa kesimpulan sebagai berikut:

1. Lirik lagu Dewa 19 merupakan simbol signifikan yang mengandung pesan dan makna. Gaya bahasa majas menjadikan makna biasa (denotatif) menjadi makna yang penuh arti (konotatif).

2. Hasil analisa menunjukkan adanya unsur kesengajaan dalam visualisasi simbol-simbol Theosofi dan Freemason dengan metode modifikasi. Pesan-pesan tidak ditampilkan secara langsung

48 Sampul Album Dewi Persik.https://www.google. co.id/imgres?imgurl

49 http://www.suryadi-putra.co.cc/2010/04/adaapa-dengan-dewa-19-ahmad-dhani-dan.html 
(eksplisit), tetapi disampaikan secara tidak langsung (implisit).

3. Kajian memperlihatkan adanya kesamaan bentuk (identik) antara simbol-simbol dalam sampul album Dewa 19 dengan simbol yang biasa terdapat pada ajaran ajaran atau paham Okultisme, Paganisme, Kaballah serta Theosofi, serta pergerakan-pergerakan rahasia Zionisme Yahudi seperti, Illuminati dan Freemasonry di seluruh dunia.

4. Terdapat struktur relasi antara lirik dan sampul kaset album grup musik Dewa 19 dengan pemahaman Theosofi dan Freemason yang diperoleh dari pemaknaan lirik-lirik lagu, pendekatan deskripsi fisik simbol, dan pendekatan historisnya.

5. Hasil analisa terhadap metode penyebaran simbol menunjukkan adanya konsistensi penyebaran simbol-simbol - simbol melalui lirik lagu, visualisasi simbol di sampul kaset album dan sebagai asesoris penampilan Dewa 19.

6. Dewa 19 masih dalam tahap terindi- kasi sebagai pengikut perkumpulan Theosofi dan gerakan Freemason, tetapi sebagai seorang pengagum atau terinspirasi dari pemahaman dari tokoh-tokoh tasawuf maka Ahmad Dhani secara nyata mengakuinya.

Saran dan rekomendasi dari penelitian ini ditujukan kepada penggemar (fans) Dewa 19, masyarakat, dan pemerintah agar waspada terhadap aktivitas penyebaran atau sosialisasi suatu nilai dari ajaran Theosofi dan Freemason yang tidak sesuai dengan identitas bangsa Indonesia.

Kajian ini secara metodologi belum mampu mengungkap dan mengukur secara mendalam dampak terhadap fans dan masyarakat. Penelitian mengenai efek atau dampak ini dapat dilakukan dan dikembangkan dengan berbagai perspektif yang terkait misalnya sosiologi, psikologi, politik dan sebagainya.Penelitian ini masih sangat terbuka untuk dilanjutkan dan dikembangkan secara lebih sempurna, terutama dengan pendekatan metodologi yang berbeda.

\section{DAFTAR PUSTAKA}

Artawijaya. 2010. Jaringan Yahudi International di Nusantara. Dari Jaman Belanda hingga Pasca Kemerdekaan RI, Jakarta: Pustaka Al Kautsar.

Bulman, Rabbi Sabshi, 2010, Yahudi Infotainment. Yogyakarta: Pustaka Solomon.

Dhani, Ahmad, Huda, Masyamsul. ed, Cetakan I Limited Edition Exclusive No.895, 2006, Manunggaling Dewa Ahmad Dhani, Jakarta: PT Serambi Semesta.

Hadi, Sutrisno. 1993. Metode Penelitian, Yogyakarta: Andi Offset.

John B. Williams', 2011. Initiation in the Masonic Life. PHILALETHES The Journal of Masonic Research E Letters, San Francisco ${ }_{L}$ http ://www.freemasonry.org, Vol. 64, No. 4, p. 144. John B. Williams. 2011. "Initiation in the Masonic Life" PHILALETHES The Journal of Masonic Research E Letters, San Francisco,http://www.freemasonry.org, Vol. 64, No. 4, p. 144.

Maulani, Z.A., 2002, Zionisme, Gerakan Menaklukan Dunia, Jakarta: Daseta.

Miles, MB.1984.Qualitative Data Analysis, Beverley Hills: Sage Pub.

Nasution, Harun, 1995, Filsafat dan Mistisisme dalam Islam, Jakarta: Bulan Bintang.

Nurdi, Herry, 2007, Jejak Freemason dan Zionis di Indonesia. Jakarta: Cakrawala Publishing. 
PROFETIKA, Jurnal Studi Islam, Vol. 17, No. 1, Juni 2016: 23-42

Pratama, Egi. 2014. Analisis Gaya Bahasa dalam Lirik Lagu Dewa 19, E-Jurnal, Jurnal.umrah. ac.id $>$ uploads $>$

Ridyasmara, Rizky. 2008. Fakta dan Data Yahudi di Indonesia. Era Repormasi, Jakarta: Pustaka Al Kautsar.

Safwat, Muh., 1978, Gerakan Freemasonry, Makkah/Jakarta: Rabitah Alam Islami.

Saidi, Ridwan dan Ridyasmara, Rizki, 2006, Fakta dan Data Yahudi di Indonesia. Jakarta: Khalifa.

Sobur, Alex, 2001, Analisis Teks Media Media; Pengantar Analisis Wacana, Analisis Semiotik dan Analisis Framing, Bandung: Remaja Rosdakarya.

2004, Semiotika Komunikasi, Bandung: Remaja Rosdakarya.

Th. Stevens, 2004, Tarekat Mason Bebas dan Masyarakat di Hindia Belanda dan Indonesia 1764 1962. Jakarta: Pustaka Sinar Harapan.

Wahyudi, Agus, 2010, Makrifat Cinta Ahmad Dhani, Yogyakarta: Penerbit Narasi.

Yahya, Harun. 2005, Ancaman Global Freemasonry, Bandung: Dzikra. 